\title{
Preposition $a ̀$ in Natioro: From comitatives to clausal conjunction
}

\section{V. Dyachkov}

Institute of Linguistics (Moscow, Russia); hyppocentaurus@mail.ru

Abstract. The paper deals with the syntax and semantics of the preposition $\grave{a}$ in Natioro, an underdescribed Gur language. This preposition is used as a comitative marker and expresses typical comitative meanings such as an instrument, companion, means of transportation etc. It can also conjoin NPs as well as finite clauses, with these two functions rarely combined in the languages of Sub-Saharan Africa. The aim of the paper is twofold. First, it describes the basic properties of comitative constructions and the positional restrictions imposed on comitative constructions of various semantic types. In particular, constructions with inanimate participants share some properties with clause-level adjuncts, and their position within the clause is fixed. In contrast, other comitative constructions have different syntactic properties and can be used in postposition to verbs as well as to nouns. This results in two possible configurations, namely the one where the comitative adjunct follows the noun it modifies, and the other where the comitative adjunct is inserted after the SOV or SVO sequence. It is also shown that all Natioro comitatives can be regarded as subordinate structures, and Natioro is a typical 'with'-language where the comitative strategy is the basic medium used to express NP conjunction. Thus, both constituents expressing NP conjunction and comitative constructions expressing other meanings can be treated in a uniform way, although the semantic relations between the head nouns in such constructions and the comitative marked NPs may differ significantly. Second, the paper gives a typologically-based overview of the phenomenon and discusses the Natioro data in comparison with other languages of the African area. Namely, it establishes some parallels with the Mande languages where comitative constructions have similar syntactic properties.

Keywords: Natioro, Gur languages, comitative constructions, comitative coordination.

Acknowledgments. The research was supported by RSCF grant №. № 17-7820071. 


\title{
Предлог ’̀ в языке натиоро: \\ от комитатива к клаузальному сочинению
}

\author{
В. В. Дьячков \\ Институт языкознания РАН (Москва, Россия); \\ hyppocentaurus@mail.ru
}

Аннотация. В статье рассматриваются синтаксис и семантика предлога $\grave{a}$ в языке натиоро (семья гур). Этот предлог используется в качестве комитативного маркера и выражает типичные комитативные значения, но может также сочинять ИГ и финитные клаузы. Совмещение этих функций нетипично для языков Африки к югу от Сахары. В статье описываются основные свойства комитативных конструкций и позиционные ограничения, характерные для таких конструкций разных семантических типов. Данные натиоро обсуждаются в сравнении с данными других языков африканского ареала.

Ключевые слова: натиоро, языки гур, комитативные конструкции, комитативное сочинение.

\section{Introduction}

The article deals with semantic and syntactic properties of comitative constructions in Natioro ( $<$ Gur $<$ Niger-Congo) spoken by some 4000 5000 speakers in several villages of Burkina Faso. The language is underdescribed, and the only sources containing some basic data on Natioro are [Prost 1968] and [Miehe, Winkelmann (eds.) 2007]. The variety discussed here is the dialect of Timba village. The data is based on my own fieldwork in 2018-2020 with a French-speaking consultant and a small corpus of oral texts collected in Timba.

The paper focuses on comitative constructions which are highly polysemous in Natioro. Comitative constructions can be subdivided into several types [Stolz et al. 2006; Arkhipov 2009a, 2009b]. Arkhipov defines the comitative construction as "an asymmetrical construction 
employed to introduce a non-obligatory participant with the same role as one of the core participants" [Arkhipov 2009a: 240]. Among such constructions, genuine comitatives are distinguished which are "used to express a non-obligatory participant set in a given situation $\mathrm{S}$, such that: (i) the predicate denoting $\mathrm{S}$ is not repeated more than once; (ii) the individual participants making up the participant set are expressed separately; (iii) the expressions denoting these participants differ in structural rank" [Ibid.: 224]. An example is an English sentence John came with Mary where there are two NPs, John and Mary, and they differ in their structural rank, John being the subject and Mary being an oblique NP. Markers used in genuine comitative constructions can also give rise to several constructions expressing closely related, but not identical meanings, such as NP coordinating structures, inclusory constructions etc. [Ibid.: 230240]. In this paper, I will consider all semantic types of comitative constructions (for a larger list, see [Stolz et al. 2006] and Section 3 of this paper).

It is well-known that in the languages of the world, there exist two main strategies of conjoining NPs, which are comitative and coordinating strategies, cf. [Stassen 2000]. All the languages can be divided into two classes with respect to which strategy is used as basic, and these languages are commonly referred to as 'WITH'- and 'AND'-languages. The former strategy is regarded as more frequent cross-linguistically and typical of Sub-Saharan languages [Ibid.]. However, 'WITH'-languages tend to evolve into 'AND'-languages, and one can see that some Natioro comitative constructions exhibit coordinating properties and some subordinating ones. Stassen also notes that languages with cases tend to be 'WITH'-languages [Ibid.: 44]. Natioro is a 'WITH'-language, as I will show below, and it does have cases, although the case system is reduced and case forms can only be found with pronouns.

In Natioro, comitative expressions are represented by constructions with prepositions. Semantically, they are associated with typical comitative meanings (such as companion, instrument, means of transportation etc.) but they are also used as markers of clausal coordination and subordination. In African languages, comitatives are frequently used 
as coordination markers connecting NPs, see [Creissels 2016; 2018], which is also true of Natioro. However, their use as clause-connecting conjunctions is not widespread. In the present paper, I will give a typologically-oriented overview of Natioro comitative constructions and describe their syntactic properties. The paper is structured as follows. Section 2 provides some basic information on Natioro. Section 3 describes semantics and syntax of comitative constructions as well as functional domains covered by them. Section 4 compares Natioro comitatives with similar constructions in languages of Sub-Saharan Africa, including the languages of Mande family which are in a longterm language contact with Natioro. The section also discusses some possible sources of grammaticalization for comitative markers, and Section 5 concludes.

\section{Natioro language}

Natioro (or Samu Kunee) is spoken by a minor community which has established long-term contacts with the neighbouring Dioula and Senufo ethnic groups. Dioula ( $<$ Mande $<$ Niger-Congo) is the lingua franca of the region and is spoken by most Natioro people. Its influence on the Natioro is obvious, and many loanwords of Dioula origin were attested in my data, including both cultural and non-cultural vocabulary. I was told that only some elder people understand Senufo, and French is not spoken in the country and not used in everyday communication. However, my consultant is one of the few Natioro people speaking French, and this language was used as intermediate in my fieldwork.

Like most African languages, Natioro is a tonal language and has three tone levels (high, mid and low). Nouns are marked by class suffixes triggering number agreement on adjectives modifying them. Class markers are suffixed to nouns and can be deleted in some contexts:

(1) $s \overline{s i s} i-\bar{a} \quad$ 'rice.cake-CL'

sis $\bar{\imath} f \bar{o}: \quad$ 'white rice cake' 
(2) kàfहु-wà 'donkey-CL'

$k a ̀ f \overline{\varepsilon \eta} k \bar{a}: b \grave{a} \quad$ 'one donkey'

Verbal derivation in Natioro is represented by a small set of affixes (causatives and TAM markers). Many TAM meanings are expressed analytically by particles which occupy the position after the clausal subject. An example is (3) where the verb is used in its Future form:

$\begin{array}{llllll}n z \varepsilon^{\bar{n}} & n \bar{a}-m i & l \bar{o}^{n} & s w e ̀=: & k w \bar{a}=: & t \bar{\jmath} \\ \text { today } & 1 \mathrm{sG}-\mathrm{OBL} & \text { FUT } & \text { go.NMLZ } & \text { market } & \text { DAT }\end{array}$

'Today, I am going to go to the market'.

In Natioro, two basic word orders must be distinguished with respect to the TAM form of the predicate. Perfective forms require SVO order, whereas Imperfective forms require SOV order. Case marking is also different in Perfective and Imperfective clauses. In clauses of the former type, the subject does not require any special case marking. In Imperfective clauses, subjects are obligatorily marked by the same case which marks direct objects (5) and is labeled as oblique. It is noteworthy that only pronouns can have special case-marked forms. Nouns do not have case forms but are subject to tonal overlays (indicated by superscripts as in (4)). The same noun can occur both with and without overlay, and it is not clear whether these overlays can be analyzed as case markers or they are due to downdrift. Hereafter, I do not mark the oblique noun forms in interlinears.

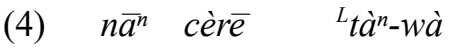

$1 \mathrm{SG}$ throw.PFV stone-CL

'I threw a stone'.

(5) $\quad n \bar{a}-m i \quad t \bar{a}^{n}-w \grave{a} \quad c \grave{r} \bar{e}-w^{n}$

1SG-OBL stone-CL throw-IPFV

'I am throwing stones'.

$\begin{array}{lll}p \overline{o \eta}-w \bar{a} & t \bar{a}: & { }^{L} n \grave{a}-m \grave{r} \\ \operatorname{dog}-\mathrm{CL} & \text { bite.PFV } & 1 \mathrm{SG}-\mathrm{OBL}\end{array}$

'A/the dog bit me'. 


\section{Comitatives in Natioro: basic properties}

\subsection{Semantic types of comitatives}

Comitative meanings are expressed in Natioro by the preposition $\grave{a}$. It is the only preposition in Natioro, since other function words are postpositions. The preposition assigns the same case which marks direct objects and which is labeled here as oblique. The most confident test revealing the case marking is using the $1 \mathrm{SG}$ pronoun $n \bar{a}$ which has a segmentally different oblique form namí. Combining it with the comitative marker, one can see that the latter is compatible only with oblique but not zeromarked forms.

$$
\begin{aligned}
& m a ́ d \bar{u} \text { pâ à } \quad * n \bar{a} / n \grave{a}-m \grave{~} \\
& \text { M. come.PFV COM 1SG 1SG-OBL }
\end{aligned}
$$

The preposition $\dot{a}$ covers a wide range of meanings which are typical of comitatives, cf. [Stolz et al. 2006]. Table 1 (p. 390) lists meanings of comitative constructions attested in [Ibid.] and gives some simple English examples. The table also indicates whether these meanings were attested in Natioro. As can be easily seen, the majority of typical comitative meanings can be expressed by the Natioro construction with $\grave{a}$, with the exception of PART-WHOLE and HUMAN INSTRUMENT meaning, which were not found in our data. The following examples illustrate some of comitative meanings.

INSTRUMENT

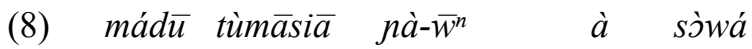

M. cultivation cultivate-IPFV COM hoe

'Madou is working in the field with a hoe'.

MEANS OF TRANSPORTATION

(9) mád $\bar{u}$ â à moto $\bar{o}=$ :

M. come.PFV COM motorcycle

'Madou has come by bike'. 
Table 1. Typical comitative contexts and examples of their realization [Stolz et al. 2006]

\begin{tabular}{|l|c|l|c|}
\hline \multicolumn{1}{|c|}{ semantic type } & Natioro & \multicolumn{1}{|c|}{ semantic type } & Natioro \\
\hline $\begin{array}{l}\text { CO-OPERATIVE } \\
\text { Mary drinks coffee with John }\end{array}$ & OK & $\begin{array}{l}\text { PART-WHOLE } \\
\text { woman with blue eyes }\end{array}$ & $(*)$ \\
\hline $\begin{array}{l}\text { RECIPROCAL } \\
\text { John kisses with Mary }\end{array}$ & OK & $\begin{array}{l}\text { POSSESSION } \\
\text { man with an axe }\end{array}$ & OK \\
\hline $\begin{array}{l}\text { ACTIVE COMITATIVE / HUMAN } \\
\text { COMPANION } \\
\text { work with other people }\end{array}$ & OK & $\begin{array}{l}\text { threaten people with } \\
\text { one's children }\end{array}$ & $(*)$ \\
\hline $\begin{array}{l}\text { CONFECTIVE } \\
\text { walk with an } \text { umbrella }\end{array}$ & OK & $\begin{array}{l}\text { MEANS } \text { one's finger } \\
\text { OF TRANSPORTATION } \\
\text { come by bicycle }\end{array}$ & OK \\
\hline $\begin{array}{l}\text { PASSIVE COMITATIVE } \\
\text { walk with a dog }\end{array}$ & OK & $\begin{array}{l}\text { MATERIAL } \\
\text { build } \text { of bricks }\end{array}$ & OK \\
\hline $\begin{array}{l}\text { TEMPORAL PROPERTY } \\
\text { come with } \text { a broken leg }\end{array}$ & OK & $\begin{array}{l}\text { TOOL } \\
\text { write by pen }\end{array}$ & OK \\
\hline $\begin{array}{l}\text { COMBINATION } \\
\text { coffee with milk }\end{array}$ & & & \\
\hline
\end{tabular}

HUMAN COMPANION

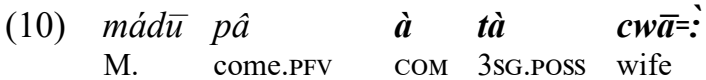

'Madou came with his wife'.

RECIPROCAL

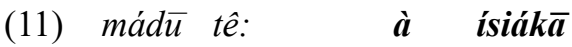

M. quarrel.PFV COM I.

'Madou quarreled with Isiaka'.

The position of comitative phrase in the clause varies with respect to the meaning of the former. First of all, it is noteworthy that the word order in Natioro is rigid and there are positions where no constituents can be inserted. The whole structure of the clause can be depicted as follows: 
(Adjunct) - Subject-Verb-(Adjunct $)$ - Direct Object-(Adjunct $)^{1}$. Adjuncts following the (Perfective) verb and the direct object ('with force') are given in (12) and (13), respectively. However, no constituent can be inserted between the subject and the verb both in Perfective and Imperfective clauses, which is illustrated by (14) and (15).

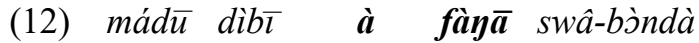

M. shut.PFV COM force house.POss-door

'Madu shut the door with force'.

$\begin{array}{lllll}\text { (13) } \quad m a ́ d \bar{u} & d \bar{\imath} b \bar{\imath} & \text { swâ-bòndà } & \grave{\boldsymbol{a}} & \boldsymbol{f a ̀ y} \overline{\boldsymbol{a}} \\ \mathrm{M} . & \text { shut.PFV } & \text { house.Poss-door } & \text { сом } & \text { force }\end{array}$

'Madu shut the door with force'.

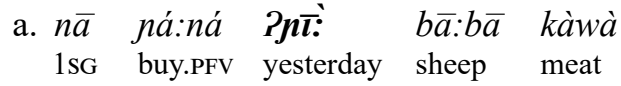

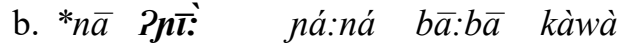
$1 \mathrm{SG}$ yesterday buy.PFV sheep meat
'Yesterday I bought some sheep meat'.
(15)

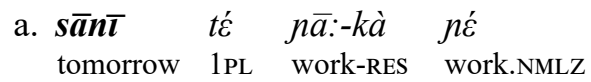
$\begin{array}{llll}\text { b. }{ }^{*} t \dot{\varepsilon} & \boldsymbol{s} \overline{\boldsymbol{a}} \overline{\boldsymbol{\imath}} & n \bar{a}:-k \grave{a} & j \varepsilon \dot{\varepsilon} \\ 1 \mathrm{PL} & \text { tomorrow } & \text { work-RES } & \text { work.NMLZ }\end{array}$
'Tomorrow we will be working'.

Comitative phrases behave like adjuncts and occupy positions that are accessible for them. However, different semantic types of comitative constructions may show different syntactic behavior. Three general restrictions come at play. The first restriction guarantees that comitatives are infelicitous in preclausal position. This restriction holds for all semantic types of comitatives and is exemplified by (16) and (17).

\footnotetext{
${ }^{1}$ Imperfective clauses follow the pattern Subject — Direct Object — Verb and the position of adjuncts is more restricted than in Perfective clauses - for instance, they cannot intervene between the direct object and the verb.
} 
$\begin{array}{clllll}\text { (16) } * \grave{a} & \text { mád } \bar{u} & \text { siat } \bar{a} & \text { swé } & k w \bar{a}=:^{\prime} & t \bar{\partial} \\ \text { СОм } & \text { M. } & \text { S. } & \text { go.PFV } & \text { market } & \text { DAT }\end{array}$

Int.: 'With Madou, Sata came to the market'.

$\begin{array}{cllll}\text { (17) } *^{*} \grave{a} & \text { súkàr } \bar{a}=: & \text { mád } \bar{u} & n \varepsilon & t \bar{\varepsilon} \\ \text { сом } & \text { sugar } & \text { M. } & \text { drink.PFV } & \text { tea }\end{array}$

Int.: 'Madou drank tea with sugar'.

The second restriction ensures that all NPs denoting inanimate participants (such as instrument, means of transportation, confective, material or tool) cannot be embedded into a simple clause. This follows from the fact that they are adjuncts but not central arguments and, therefore, they can only occur in positions accessible for adjuncts. For instance, in (18) they cannot be inserted between the subject and the verb, since no constituents can appear in this position. However, this position is accessible for some comitative constructions, for instance, those denoting human companions (19). As will be shown below, these comitatives are in fact dependents of the head (= leftmost) NP and form a constituent with it. In contrast, inanimate participants, when inserted in this position, are infelicitous, since they are reinterpreted as a part of conjoined NP construction (20).

$$
\begin{aligned}
& \text { a. } m a ́ d u \quad p \hat{a} \quad \text { à } \quad \boldsymbol{m} \overline{\boldsymbol{o}} \overline{\boldsymbol{o}}=: \\
& \text { M. come.PFV COM motorcycle }
\end{aligned}
$$

'Madou has come by motorcycle'.

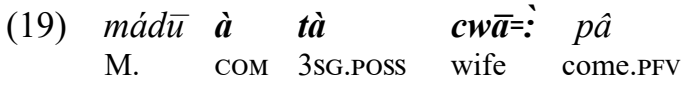

'Madou came with his wife'.
${ }^{\#}$ siāta $\grave{a} \quad \boldsymbol{t a ̀}$
māráf $\bar{a}=: \vdots \quad n a ̀ k a ̀-\bar{w}^{n}$
S. COM 3sG.POSS rifle march-IPFV
\#‘Sata and her gun are walking'.

The sentences (18)-(20) are intransitive clauses, but the same effect can be observed with transitive verbs which also do not allow intervening 
comitative phrases. In the example below, the verb is Perfective and the comitative phrase cannot be inserted between it and its direct object.

$$
\begin{array}{lllll}
* m a ́ d \bar{u} & s \tilde{c}^{n} & \grave{a} & \boldsymbol{s} \overline{\boldsymbol{o}}^{n}-\boldsymbol{w} \overline{\boldsymbol{a}} & k \grave{a} w-\grave{a} \\
\mathrm{M} . & \text { cut.PFV } & \text { COM } & \text { knife-CL } & \text { meat-CL }
\end{array}
$$

Int.: 'Madou cut the meat with a knife'.

Some exceptions to the second restriction known to me are the following examples where the subject is followed by participants which are not active. It is PASSIVE COMITATIVE in (22) and TEMPORAL PROPERTY in (23). In both cases, the participant marked by $a$ is followed by resultative participles that constitute a separate clause in Natioro. Taking this fact into consideration, I assume that these examples are somehow structurally different from all the examples above where no separate clauses are present. However, no account of this fact can be proposed at the moment.

$\begin{array}{llllll}\text { siāt } \bar{a} & \grave{a} & t a ̀ & p y \bar{a} & \text { māmá-ká } & n a ̀ k \grave{a}-\bar{w}^{n} \\ \mathrm{~S} . & \text { COM } & \text { 3sG.POSS } & \text { child } & \text { fetch.on.back-RES } & \text { march-IPFV }\end{array}$

'Sata is walking with her child on her back'.

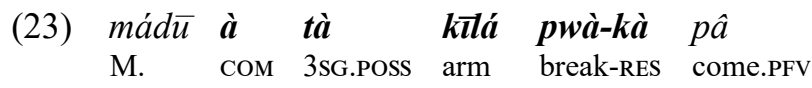

'Madou came with a broken arm'.

Comitative phrases denoting animate companions behave differently from inanimate ones. Their position within the clause may vary - they are felicitous in postposition both to nouns and verbs.

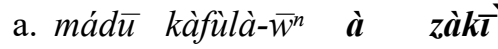
M. chat-IPFV COM Z.

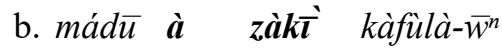

M. COM Z. chat-IPFV

'Madou and Zaki are chatting with each other'.

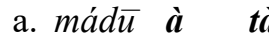
$\boldsymbol{c w} \overline{\boldsymbol{a}}=: \quad p \hat{a}$
M. COM 3sG.POSs wife come.PFV
'Madou came with his wife'. 


\section{b. $m a ́ d \bar{u}$ pâ $\quad \grave{a} \quad$ tà $\quad \boldsymbol{c w} \overline{\boldsymbol{a}}=:$ \\ M. come.PFV COM 3sG.POSs wife \\ 'Madou came with his wife'.}

Comitatives denoting animate companions cannot be detached too far from the noun they modify. In (24) and (25), the comitative constituent is close to the noun, and they are only separated by the verb. In other cases like (26), the comitative is detached from the subject and is reinterpreted as an instrument-denoting constituent. The meaning of concomitance ('together with $X$ ') is inaccessible in such contexts, suggesting that it is prone to be expressed via juxtaposition of the head NP and comitative.

$\begin{array}{lllll}{ }^{\#} m a ́ d \bar{u} & t u ̀ m a \bar{a} \bar{a} & n \grave{a}-\bar{w}^{n} & \grave{a} & \text { siāt } \bar{a} \\ \mathrm{M} . & \text { cultivation } & \text { cultivate-IPFV } & \text { COM } & \text { S. }\end{array}$

\#‘Madou is cultivating (= working in the field) using his wife [as an instrument]'.

*'Madou is cultivating together with his wife'.

The preposition $a ̀$ can be also used in nominal conjunction contexts, as predicted by the semantic map in [Haspelmath 2004: 20]. In Natioro, there are two different ways to express the conjunction. Apart from comitative markers, the conjunction $\mathrm{mi}^{-}$is also used in this function. However, the two conjunctions can be easily distinguished, since $m i^{-}$is semantically restricted and can only be used with animate nouns, as can be seen in (28) and (29).

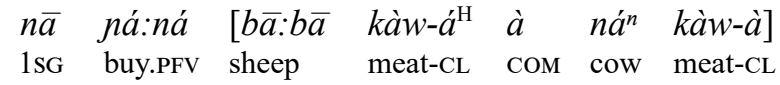

'I bought sheep meat and beef'.

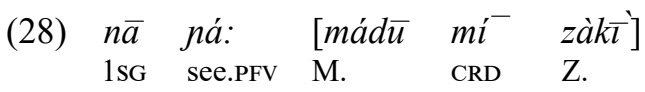

'I saw Madou and Zaki'.

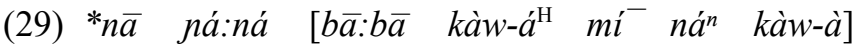
$1 \mathrm{SG}$ buy.PFV sheep meat-CL CRD cow meat-CL

Int.: 'I bought sheep meat and cow meat'. 
As predicted in [Haspelmath 2004], noun-linking conjunctions can develop into verb-linking ones. In Natioro, $\grave{a}$ can conjoin VPs as well as clauses. Examples of two VPs ${ }^{2}$ coordinated by $\grave{a}$ are given in (30) and (31).

$\begin{array}{llll}m a ́ d \bar{u} & k \bar{l} \bar{\imath} \bar{\eta}=g \bar{a} & \grave{\boldsymbol{a}} & \boldsymbol{w} \overline{\boldsymbol{l}} \overline{\boldsymbol{D}} \\ \mathrm{M} . & \text { lie=RES } & \text { COM } & \text { go.to.sleep.PFV }\end{array}$

'Madou lay down and slept'.

\begin{tabular}{|c|c|c|c|c|c|c|}
\hline $\begin{array}{l}{[n i} \\
\text { 1SG.OBL }\end{array}$ & $\begin{array}{l}m \bar{a} \\
2 \mathrm{sG}\end{array}$ & $\begin{array}{l}\text { pin- } \bar{\varepsilon}] \\
\text { ask-NMLZ }\end{array}$ & $\begin{array}{ll}\grave{a} & {[m a ́} \\
\mathrm{COM} & 2 \mathrm{sG}\end{array}$ & $\begin{array}{l}\text { t'́ } \\
\text { PST }\end{array}$ & $\begin{array}{l}l \overline{o^{n}} \\
\text { FUT }\end{array}$ & $\begin{array}{l}s w \hat{e} \\
\text { come.NMLZ }\end{array}$ \\
\hline$c \grave{\varepsilon}: n \overline{\varepsilon s} \bar{a}=$ & $s \bar{l}]$ & [má & $p-\bar{e}:$ & $n \grave{a}-\bar{w}^{n}$ & $\grave{a}$ & 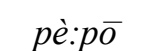 \\
\hline hunt & LOC & 2SG.OBL & thing-PL & do-IPFV & СОМ & I what \\
\hline $\bar{a}=n$ & $w \bar{a} ?]$ & & & & & \\
\hline ke-IPFy & Q & & & & & \\
\hline
\end{tabular}

'I would like to ask you: if you would go hunting, what do you do and what do you take $\{$ with you $\}$ ?'

Of interest is the fact that $\grave{a}$ can be used both as a coordinating and subordinating conjunction. Although its position is fixed and the marker occupies the leftmost slot in the clause, there are at least two different types of contexts where $\grave{a}$ can be used. First, it can link two independent clauses, cf. (31) and (32). Second, it is used to mark conditional antecedents as in (33). Third, it can introduce some sentential arguments (34).

\begin{tabular}{|c|c|c|c|c|}
\hline $\begin{array}{l}{[m a ́} \\
2 \mathrm{SG}\end{array}$ & $\begin{array}{l}y \bar{r} \bar{a} \\
\text { invite }\end{array}$ & $\begin{array}{l}s \overline{a m u ́}-t \overline{\varepsilon n}-j \dot{\varepsilon}] \\
\text { person-man.PL-PL }\end{array}$ & $\begin{array}{l}\grave{a} \\
\mathrm{COM}\end{array}$ & $\begin{array}{l}{\left[k \bar{\varepsilon}^{n}-t \overline{\varepsilon n} j \bar{\varepsilon}\right.} \\
\text { marabout-person.PL }\end{array}$ \\
\hline & & & & \\
\hline
\end{tabular}

'You invite people, and marabouts come to baptize a child'.

${ }^{2}$ In fact, both (30) and (31) are not pure cases of VP coordination. There is no additional evidence that two Perfective verbs linked by $\grave{a}$ in (30) form a coordinate and not subordinate structure. Imperfective clauses in (31) might have nominal properties and, taken as such, are not structurally different from coordinate nominal constructions discussed above. So, the problem needs further research. 


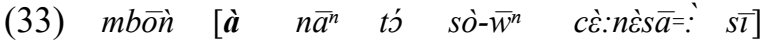
well COM 1SG PST go-IPFV hunt LOC

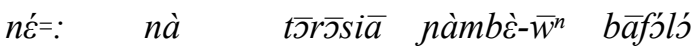

1SG.OBL 1sG.POSS torch make-IPFV first

'Well, if I would go hunting, I am verifying my torch first'.

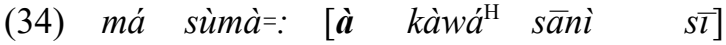

2SG know COM meat this.place LOC

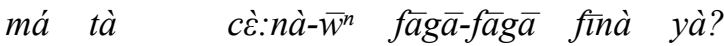

2SG 3SG.Poss hunt-IPFV in.such.way what $Q$

'If you know that the animal is there, how do you hunt it?'

\subsection{Syntax of comitative constructions:}

\section{Coordination vs. subordination}

In the previous section, I have shown that comitative constructions differ in their syntactic behavior. Below, I will show that these differences partially correlate with the parameter of (a)symmetry between the two NPs constituting a comitative construction.

Constructions expressing inanimate participants such as instruments or means of transportations are adjuncts, although they do not occur clause-initially or cannot be embedded like, say, temporal adjuncts. In these constructions, semantic relations between the clausal subject and the comitative-marked NPs are asymmetrical. For instance, in (9) repeated here as (35), the semantic role of the NP 'Madou' is not the same as the semantic role of the NP 'motorcycle'.
$\begin{array}{llll}m a ́ d \bar{u} & p \hat{a} & \grave{a} & m \bar{o} t \bar{o}=: \\ \mathrm{M} . & \text { come.PFV } & \text { COM } & \text { motorcycle }\end{array}$
'Madou has come by motorcycle'.

In contrast, constructions where relations between the head NP and the comitative phrase are symmetrical represent a different case. For instance, in (10) repeated here as (36) the NPs 'Madou' and 'his wife' have the same semantic role, since both participants are involved in the action in the same way. 
What brings these constructions together with VPs or clause-level adjuncts discussed above is the fact that some of them can be detached from the NP they are related to. This is illustrated by (36) and (19), repeated here as (37).

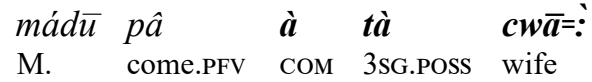
'Madou came with his wife'.

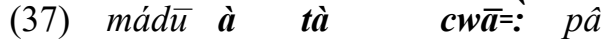
M. COM 3sG.POSS wife come.PFV

'Madou came with his wife'.

My data show that symmetrical comitatives cannot be unambiguously classified as coordinating or subordinating constructions. If these constructions are indeed those having some coordinating properties, then some of their properties can be accounted for straightforwardly. For instance, in (26) two NPs cannot be detached from each other, like any coordinated constituents. The fact that extraposition of the comitative construction, as in (16), is impossible would also be expected for coordinate structures.

However, some additional examples show that, at least in some cases, semantically symmetrical constructions pattern together with adjunct comitatives. Evidence comes from interrogation of NP constituents. In Natioro, wh-words tend to remain in situ, which is exemplified in (38). Separate interrogation of coordinated constituents is usually ungrammatical, which is an instantiation of the Coordinate Structure Constraint as formulated by [Ross 1967]. I have already shown that comitative constructions can be used in contexts which are typical of coordination (' $\mathrm{X}$ and $\mathrm{Y}$ '). However, these constructions are not subject to Coordinate Structure Constraint since one of conjoined NPs can be interrogated separately from another, see (39).

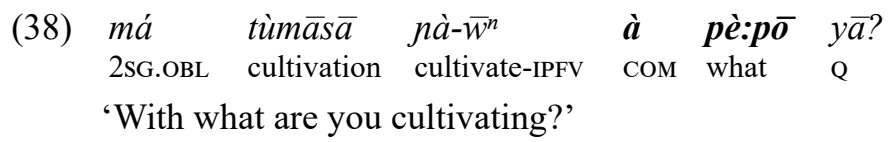

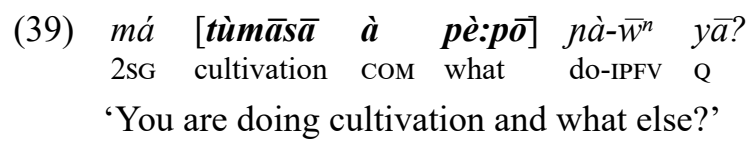


I have not applied other tests which can be used in order to distinguish coordinating and subordinating syntactic structures, and this question needs further research. However, there is an additional argument in favor of the subordination analysis. As was shown in the beginning of Section 2, the constituent marked by à receives the oblique case, suggesting that it does not share case marking with the head NP. Thus, comitative-marked constituents are prone to be dependents rather than constituents equal in their syntactic status with the noun they are attached to. If this is so, then all comitatives have to be regarded as dependent phrases. Asymmetrical comitatives exemplified in (38) are adjuncts due to their position within a clause. Symmetrical comitatives exemplified in (39) are also dependent constituents which do not change their position and cannot be neither extracted leftwards nor detached from the head noun. It is noteworthy that the structure of clause-level adjunct comitatives is parallel to the structure of postnominal comitatives in that both are located right to their heads.

Comitative markers used as clause-linking conjunctions can be potentially subdivided into coordinating and subordinating structures. We have already seen that $\grave{a}$ linking clauses can be used as a conditional antecedent marker as well as a marker of simple clause conjunction ('and'), suggesting that there are at least two different underlying structures. Available elicited examples show that the latter exhibit some coordination properties which can be revealed by ellipsis. For instance, the following Russian clauses can be differentiated by their ability to undergo elliptical deletion. Clauses containing a coordinating conjunction $i(40)$ allow it, while subordinated clauses containing kogda do not (41).

$\begin{array}{llllll}\text { Segodnya } & \text { ya } & \text { rabotal, } & \boldsymbol{i} & \text { Vasiliy } & \text { tozhe. } \\ \text { today } & 1 \mathrm{SG} & \text { work.PFV } & \text { and } & \text { V. } & \text { also }\end{array}$

'Today I worked, and Vasiliy as well'.

$\begin{array}{llllll}* \text { Segodnya } & \text { ya } & \text { rabotal, } & \text { kogda } & \text { Vasiliy } & \text { tozhe. } \\ \text { today } & 1 \mathrm{Sg} & \text { work.PFV } & \text { when } & \text { V. } & \text { also }\end{array}$

Int.: 'Today I worked, when Vasiliy as well'.

If the Natioro marker $\grave{a}$ is used as a conjunction marker, it patterns with coordinating but not subordinating structures, compare (41) and (42). 


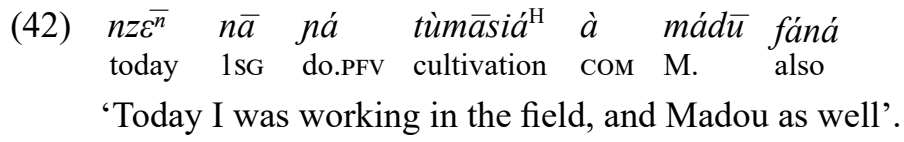

However, it is well-known that same markers may exhibit both properties of coordination and subordination in different contexts (see, for instance, [Belyaev 2015] for a possible solution of the problem). Thus, a more thorough investigation of clausal conjunction in Natioro is the subject of future research.

\section{Typology of the phenomenon and Sub-Saharan comitatives}

To sum it up, Natioro can be regarded typologically as a 'WITH'-language where the comitative marker can be used as a marker of conjunction as well. Conjoined NPs exhibit some properties of subordinating structures, and the Natioro data fit well in typological generalizations.

Unexpected is the fact that the same marker is used for NP and clause conjunction, which seems to be a rare phenomenon in Sub-Saharan languages. Welmers claims that he is not aware of any African languages where verbal and NP conjunction is expressed by the same marker [Welmers 1973: 365]. Creissels notes that in Sub-Saharan languages "the grammatical word or clitic used for the additive coordination of NPs tends to be used also as a comitative adposition" [Creissels 2016: 15]. He also observes that "among Sub-Saharan languages, the use of the same grammatical word or clitic for the additive coordination of NPs and for the additive coordination of clauses is not common" [Ibid.: 15]. From the above analysis, it can be easily seen that, indeed, the first generalization might be confirmed by the Natioro data since the same marker is used in coordinating constructions (' $\mathrm{X}$ and $\mathrm{Y}$ ') and as a comitative preposition. In contrast, the second observation is not relevant for Natioro, since the comitative preposition is also used as a clause-linking conjunction. 
Although the same marker is used in many languages of the African area for coordination and subordination, the difference between VP/ clause-level comitatives and comitative coordination can be revealed by additional tests. For instance, in Tswana ( $<$ Bantu $<$ Niger-Congo) the two constructions can be distinguished by their ability to trigger the verbal agreement. Clause-level comitatives do not affect the agreement (43), and the verb bears the same class marker as the subject. In contrast, when a comitative construction follows nouns as in (44), the verb bears a plural class marker reflecting the plural feature of the NP it agrees with.

Tswana

$\begin{array}{lll}\text { kitsó } & \text { Ú-tsilé } & \text { lí-m̀:ph } \\ \text { (CL1)Kitso } & \text { cL1-come.PRF.CJ } & \text { with-(CL1)Mpho }\end{array}$

'Kitso came with Mpho'.

(44) kitsó

$$
l i ́-\grave{m} p^{h} \dot{\partial}
$$

${ }^{\downarrow} b a ́-t s \hat{i}: l e ̀$

(CL1)Kitso with-(CL1)Mpho CL2-come.PRF.DJ

'Kitso and Mpho came'. [Creissels 2016: 26]

In other Sub-Saharan languages, comitative constructions can be used as markers subordinating one NP to another. This is the case of the Mande languages. According to [Creissels 2018: 738-740], in Mandinka the comitative marker $n \hat{\imath} \eta$ can be used in coordinating contexts as well as in subordinating ones. He cites sentences like (45) as examples of coordination of two NPs. However, it is not clear what tests were used to reveal the coordinating properties of such constructions. Other contexts where nîy can be used are examples like (46) where an NP subordinates another (deverbal) NP. These constructions are used to express the manner in which an action is performed.

(45) yá

[ñòôn níy tìyóo] sèné.

1SG.CPL millet.D with peanut.D cultivate

'I cultivated millet and peanuts'. [Creissels 2018: 739]

(46) [kàmbàanóo níy bòróo] năa-tà.

boy.D with running.D come-CPL

'The boy came running (lit. The boy with running came)'. [Ibid.: 740] 
When used postverbally, comitatives must preserve their structure $\left[\mathrm{N}_{1}\right.$ $n \hat{\imath} \eta \mathrm{N}_{2}$ ] and include a resumptive pronoun:

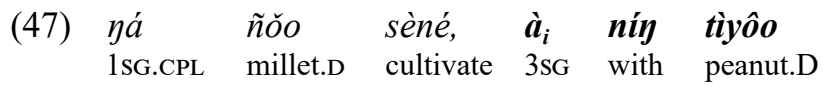

'I cultivated millet, and also peanuts [lit. it with peanuts]'. [Creissels 2018: 740]

Another important feature noted in [Creissels 2018] is the fact that elements of the comitative construction can be marked independently with focus. For instance, in (48), the focus marker follows the first conjunct, and Creissels claims that such operations are not possible with coordinating structures.

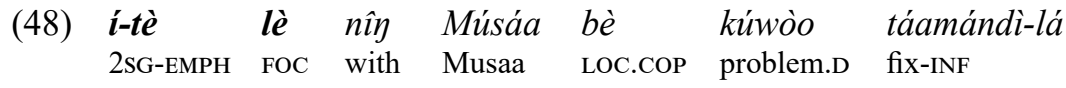

'You will fix the problem with Musaa'. [Creissels 2018: 741]

To summarize, the facts presented in [Creissels 2018] suggest that Sub-Suharan comitative constructions are represented by at least two different types. In Tswana, comitatives can follow both clauses and NPs, like their Natioro counterparts. In two cases, their syntactic structures are different and they affect verbal agreement in different ways. In Natioro, this criterion cannot be applied straightforwardly since verbs lack agreement markers. The second type of comitative constructions is represented by Maninka where NP conjunction is expressed by a comitative marker and this construction is regarded as a subordinate structure.

I have shown in previous sections that Natioro comitatives can be subdivided into at least two subclasses and that NP- and clause level-adjuncts can be distinguished. What brings together Maninka and Natioro constructions is the fact that conjoined NPs can be independently subject to similar processes such as interrogation (Natioro) and focalization (Maninka). At the same time, in Maninka comitative markers are also used to mark dependent converb clauses, which is not a frequent polysemy pattern but can be also found in Chukotko-Kamchatkan and Caucasian languages [Arkhipov 2009b: 196-197].

A question arises whether comitative markers in Natioro can be structurally similar to Mande ones and whether prepositional comitatives can 
be regarded as an areal feature, which might have arisen due to language contacts. My consultant claimed that $\grave{a}$ is not an original Natioro preposition but a loanword, but I cannot find any direct evidence of this. However, comitative prepositions are presumably an areal phenomenon, since Mande comitatives are structurally similar to Natioro constructions. In Natioro, the comitative marker is the only preposition, and this structural property is shared by many Mande languages which are basically SOV languages with postpositions. The comitative marker is the only preposition in a Mande language Boko [Perekhvalskaya 2017]. In many other Mande languages, comitatives are also prepositions but not postpositions, see for instance, [Idiatov, Aplonova 2017] for information on Tura and [Konoshenko 2017] for Kpelle.

Simultaneously, my consultant felt some association of $\grave{a}$ with the 3sG pronoun. In Natioro, its initial form is $\bar{a}$ :

$$
\begin{aligned}
& \bar{a} \quad n \bar{\varepsilon}=: \\
& \text { 3sG } \quad \text { drink.PFV=MED } \\
& \text { 'He drank'. }
\end{aligned}
$$

Tonal contours of the comitative marker and the 3sG pronoun are different, and a process which would "lower" the tone of the latter needs to be justified if the two markers are indeed associated with each other. However, I would not exclude this possibility from consideration. Moreover, some typological observations suggest that clausal coordination may involve comitatives combined with pronouns [Arkhipov 2009b: 44-48].

Although it is not clear whether the comitative marker was borrowed or not, we have to suppose that $\grave{a}$ conjoining clauses is the result of functional extension of $a$ conjoining NPs, as suggested by [Haspelmath 2004] and [Arkhipov 2009b: 44-48]. However, it is noteworthy that if NP conjunction is expressed by a subordinate construction, as I suggested, it is hard to explain how a subordinate construction (NP $+\grave{a}+\mathrm{NP})$ could have evolved into a coordinate structure (clause $+\grave{a}+$ clause). Thus, another scenario can be proposed according to which structures of both types can be reduced to a single invariant. However, a detailed investigation of this problem goes beyond the scope of this paper. 


\section{Conclusion}

In this paper, I have explored some basic properties of comitative constructions in the Natioro language. I have shown that Natioro is a language where the comitative strategy is used in typical comitative contexts as well as in contexts of NP coordination. Nominal conjoined constructions can be treated on a par with postverbal adjuncts, since they both have subordination properties. Among the languages of Sub-Saharan Africa, Natioro is standing out since clauses are conjoined using the same comitative marker which is used to conjoin NPs, which is quite atypical of the languages of the area. Moreover, the comitative marker used as a clause linker, has various meanings and is used as a marker of conjunction, as a conditional antecendent marker and as a conjunction introducing some sentential arguments.

The Table 2 summarizing some of the properties investigated in this paper is given below.

Table 2. Summary: Properties of different types of comitative constructions in Natioro

\begin{tabular}{|c|c|c|c|}
\hline & $\begin{array}{c}\mathbf{N P} \\
\text { conjunction } \\
(\mathbf{N}+\grave{a}+\mathbf{N})\end{array}$ & $\begin{array}{c}\text { clausal adjunct } \\
\text { comitatives } \\
(\mathbf{S}+\grave{a}+\mathbf{N})\end{array}$ & $\begin{array}{c}\text { clause } \\
\text { conjunction } \\
(\mathrm{S}+\grave{a}+\mathbf{S})\end{array}$ \\
\hline syntactic relation & subordination & subordination & $\begin{array}{l}\text { (coordination/ } \\
\text { subordination) }\end{array}$ \\
\hline $\begin{array}{l}\text { semantically } \\
\text { symmetrical } \\
\text { relations }\end{array}$ & possible & impossible & possible \\
\hline $\begin{array}{l}\text { interrogation of the } \\
\text { comitative-marked } \\
\text { constituent }\end{array}$ & yes & yes & - \\
\hline $\begin{array}{l}\text { preposition } \\
\text { of ComP }\end{array}$ & no & no & - \\
\hline
\end{tabular}


Based on syntactic tests, three types of comitative constructions can be distinguished in Natioro - constructions expressing NP conjunction, clause conjunction, and adjunct comitatives. All three types are subordinate structures, but it is possible that the comitative marker $\grave{a}$ is used for both coordination and subordination of clauses, which must be investigated further in detail. Symmetrical semantic relations between the head $\mathrm{NP}$ and its dependent are possible in comitative constructions expressing conjunction (' $\mathrm{X}$ and $\mathrm{Y}$ '). In constructions expressing nominal conjunction, conjuncts can be interrogated separately, which brings these constructions together with adjunct comitatives. Finally, all types of comitatives cannot be used in preposition to the main clause and this property distinguishes them from other types of adjuncts.

\section{Abbreviations}

$=-$ vowel lengthening; $1,2,3-1^{\text {st }}, 2^{\text {nd }}, 3^{\text {rd }}$ person; $\mathrm{CJ}-$ conjoint (form); $\mathrm{CL}-$ classifier; COM - comitative; COP - copula; $\mathrm{CPL}$ - completive; $\mathrm{CRD}$ - coordinating conjunction; D - definite; DAT — dative; DJ — disjoint (form); EMPH - emphatic; FOC - focus; FUT - future tense; $\mathrm{H}$ - tone raising; INF - infinitive; IPFV - Imperfective; LOC — locative; MED — middle voice; NMLZ — nominalization; OBL — oblique; PFV — Perfective; PL — plural; POss — possessor; PRF — perfect; PST — past tense; Q question particle; RES - resultative; $\mathrm{SG}$ - singular.

\section{References}

Arkhipov 2009a - A. V. Arkhipov. Comitative as a cross-linguistically valid category. W. Bisang (ed.). New Challenges in Typology 2: Transcending the Borders and Refining the Distinctions. (Trends in Linguistics. Studies and Monographs 217). Berlin; New York: Mouton de Gruyter, 2009. P. 223-246.

Arkhipov 2009b - A. V. Arkhipov. Tipologiya komitativnykh konstruktsiy [Typology of Comitative Constructions]. Moscow: Znak, 2009.

Belyaev 2015 - O. I. Belyaev. Systematic mismatches: Coordination and subordination at three levels of grammar. Journal of Linguistics. 2015. Vol. 51. Iss. 2. P. 267-326.

Creissels 2016 - D. Creissels. Additive coordination, comitative adjunction, and associative plural in Tswana. Linguistique et langues africaines. 2016. Vol. 2. P. 11-42. 
Creissels 2018 - D. Creissels. Current issues in the morphosyntactic typology of Sub-Saharan languages. T. Güldemann (ed.). The languages and Linguistics of Africa. (The World of Linguistics 11). Berlin; Boston: Mouton de Gruyter, 2018. P. 712-821.

Haspelmath $2004-$ M. Haspelmath. Coordinating constructions: An overview. M. Haspelmath (ed.). Coordinating Constructions. (Typological Studies in Language 58). Amsterdam; Philadelphia: Benjamins, 2004. P. 3-39.

Idiatov, Aplonova 2017 - D. I. Idiatov, E. S. Aplonova. Tura yazyk [Tura language]. V. F. Vydrin, Yu. V. Mazurova, A. A. Kibrik, E. B. Markus (eds.). Yazyki mira: Yazyki mande [Languages of the World: Mande Languages]. St. Petersburg: Nestor-Istoriya, 2017. P. 583-616.

Konoshenko 2017 - M. B. Konoshenko. Kpelle yazyk [Kpelle language]. V. F. Vydrin, Yu. V. Mazurova, A. A. Kibrik, E. B. Markus (eds.). Yazyki mira: Yazyki mande [Languages of the World: Mande Languages]. St. Petersburg: Nestor-Istoriya, 2017. P. 284-343.

Miehe, Winkelmann (eds.) 2007 - G. Miehe, K. Winkelmann (eds.). Noun Class Systems in Gur Languages. Vol. 1: Southwestern Gur Languages (without Gurunsi). (Gur Monographs 9). Köln: Rüdiger Köppe Verlag, 2007.

Perekhvalskaya 2017 - E. V. Perekhvalskaya. Boko yazyk [Boko language]. V. F. Vydrin, Yu. V. Mazurova, A. A. Kibrik, E. B. Markus (eds.). Yazyki mira: Yazyki mande [Languages of the World: Mande Languages]. St. Petersburg: Nestor-Istoriya, 2017. P. 1051-1093.

Prost 1968 - A. Prost. Deux langues voltaïques en voie de disparition: le wara et le natioro. (Documents linguistiques 14). Dakar: Publications de Département de linguistique générale et linguistique africaine de la Faculté des lettres et sciences humaines de l'Université de Dakar, 1968.

Ross 1967 - J. R. Ross. Constraints on Variables in Syntax. PhD thesis. Cambridge: MIT, 1967.

Stassen 2000 - L. Stassen. AND-languages and WITH-languages. Linguistic Typology. 2000. Vol. 4. Iss. 1. P. 1-54.

Stolz et al. 2006 - T. Stolz, C. Stroh, A. Urdze. On Comitatives and Related Categories: A Typological Study with Special Focus on the Languages of Europe. (Empirical Approaches to Language Typology 33). Berlin: Mouton de Gruyter, 2006.

Welmers 1973 - W. E. Welmers. African Language Structures. Berkeley; Los Angeles; London: University of California Press, 1973. 